\title{
Microbial Inoculants for Improving Crop Quality and Human Health in Africa
}

\section{Elizabeth Temitope Alori' and Olubukola Oluranti Babalola ${ }^{2 *}$}

${ }^{1}$ Department of Crop and Soil Science, Landmark University, Omu-Aran, Nigeria, ${ }^{2}$ Food Security and Safety Niche Area, Faculty of Natural and Agricultural Sciences, North-West University, Mahikeng, South Africa

Current agricultural practices depend heavily on chemical inputs (such as fertilizers, pesticides, herbicides, etc.) which, all things being equal cause a deleterious effect on the nutritional value of farm product and health of farm workers and consumers. Excessive and indiscriminate use of these chemicals have resulted in food contamination, weed and disease resistance and negative environmental outcomes which together have a significant impact on human health. Application of these chemical inputs promotes the accumulation of toxic compounds in soils. Chemical compounds are absorbed by most crops from soil. Several synthetic fertilizers contain acid radicals, such as hydrochloride and sulfuric radicals, and hence increase the soil acidity and adversely affect soil and plant health. Highly recalcitrant compounds can also be absorbed by some plants. Continuous consumption of such crops can lead to systematic disorders in humans. Quite a number of pesticides and herbicides have carcinogenicity potential. The increasing awareness of health challenges as a result of consumption of poor quality crops has led to a quest for new and improved technologies of improving both the quantity and quality of crop without jeopardizing human health. A reliable alternative to the use of chemical inputs is microbial inoculants that can act as biofertilizers, bioherbicide, biopesticides, and biocontrol agents. Microorganisms are able to carry out the plant growth promotion, pest and disease and weed control. Microbial inoculants are beneficiary microorganisms applied to either the soil or the plant in order to improve productivity and crop health. Microbial inoculants are natural-based products being widely used to control pests and improve the quality of the soil and crop, and hence human health. Microbial inoculants involve a blend of microorganisms that work with the soil and the soil life to improve soil fertility and health and by extension improve human health. Microbial inoculants have the ability to minimize the negative impact of chemical input and consequently increase the quantity and quality of farm produce. Microbial inoculants are environmental-friendly and deliver plant nutrients to plants in a more sustainable manner. Microbial inoculants can help reduce chemical fertilizer application. Microbial inoculants could include bacteria, fungi and algae. This research summarizes the impact of agricultural chemical inputs on human health. The contribution of microbial inoculants in sustainable maintenance of human health will be expatiated. Advances in microbial inoculants and technology and strategies to explore this natural, user friendly biological resource for sustainable maintenance of plant health will be discussed.

Keywords: microbial inoculants, human health, biofertilizers, biocontrol agents, plant growth promoting rhizobacteria (PGPR) 


\section{INTRODUCTION}

The advent of industrial system of agriculture involving the use of chemicals, preservatives, hormones, and antibiotics resulted in increased food growth and production (Alori and Fawole, 2017b). This new technique produces crop and livestock in larger quantities than the sustainable agriculture practiced in the past (Gilchrist et al., 2007). Industrial agriculture is characterized with mono cropping, in which the same crop is grown season after season. Mono cropping reduces the soil's ability to naturally eliminate pests and replenish nutrients (Alori and Fawole, 2017a). To combat this menace industrial agriculture uses heavy doses of chemical fertilizers and pesticides (Alori et al., 2017a). Similarly, massive quantities of livestock such as cows, chickens, pigs, and turkeys are raised in confined, overcrowded and unsanitary conditions (Schmidt, 2002; Sayre, 2009).

Agrochemicals are commonly used in agricultural production to control or prevent diseases, pests and weeds in order to maintain high quality of agricultural products and eliminate or reduce yield losses. With this industrialized system, food is produced at reduced costs and farmers therefore get higher profits from their farm but serious concerns were being raised about health risks resulting from residues in drinking water and food and from occupational exposure (Alori and Fawole, 2017b). Suyal et al. (2016), reiterated that heavy doses of chemical fertilizer, although leading to self-reliance in food production, causes harmful impacts on living organisms and also depreciate the environment. The chemical contaminates the food produced and goes further to alter the normal body functions of the consumer (Sayre, 2009). Baker et al. (2002), reported $75 \%$ of pesticide residues in conventionally grown produce. Water supplies are polluted by toxic insecticides, herbicides, and chemical fertilizers used (Alori et al., 2017b).

One of the factors that increase susceptibility of farm workers to the injurious effects of agro-chemicals include language barrier. Most local farmers are illiterates; this hinders their understanding and adoption of safety precautions on labels and training in proper work practices. Lack of background in agriculture by most hired farm workers who use employment in the agricultural sector as an entry-level job may increase health and safety hazards in the agricultural workplace. It is therefore imperative to seek an alternative technology that will boost food production to meet the food requirements of the ever growing world population while minimizing the health hazards they pose to the environment, humans, and farm animals.

Microbial inoculants refer to formulations composed of beneficial microorganisms that play an important role in soil ecosystems for sustainable agriculture. Microbial inoculants are environmentally friendly and are a potential alternative to chemical fertilizers and pesticides (Babalola and Glick, 2012). They are composed of active strains of microorganisms which directly or indirectly stimulate microbial activity and hence improve mobility of nutrients from soil (Suyal et al., 2016). They could be phyto-stimulants, bio-fertilizers or microbial biocontrol agents (Alori et al., 2017b). They provide protection against a range of different pathogens and they are effective bio-herbicides (Babalola, 2010b).
In view of these, this paper aims to summarize the impact of the conventional agricultural inputs (fertilizers, pesticides, and herbicides) on human health and the ameliorating effect of microbial inoculants on these hazards. Advances in microbial inoculants and technology and strategies to explore this natural, user friendly biological resource for sustainable maintenance of plant health will be discussed.

\section{IMPACT OF AGRICULTURAL INPUTS (FERTILIZERS, PESTICIDES AND HERBICIDES) ON HUMAN HEALTH}

Due to increasing numbers of people in farming, in the vicinity of farming areas and consumers of contaminated farm products, agricultural chemical inputs have currently become major public health problems (Alori et al., 2017a,b). Agro-chemical runoff is a major contributor to surface-water contamination (Wohlfahrt et al., 2010). Excess and wrong usage of chemical fertilizers result in soil washing, contamination of ground water, streams, and sea (Önder et al., 2011). Agricultural chemical inputs gain access into human body systems through three major means: (1) oral ingestion, (ii) infiltration through the skin, and (iii) breathing (Roychowdhury et al., 2014). Pesticides have shown long-term resistance in food including vegetables, meat, and fruits, and in the human body (Battu et al., 2005). Quite a number of people are negatively affected by long-term exposure to agrochemicals, even at low levels (Kirkhorn and Schenker, 2001). The illnesses range from respiratory disorders and musculoskeletal illnesses to dermal and cardiac related diseases. These illnesses are encountered by farm owners, operators, family members, and employees (Magauzi et al., 2011).

Factors that were responsible for the susceptibility of farm owners and workers to agrochemical poisoning include inadequate protective clothing and safety systems, lack of knowledge of the caution code for hazardous agrochemicals (Magauzi et al., 2011). The study in Nepal, India by (Bhandari, 2014), also confirmed that only $2.33 \%$ of the farm owners and workers had received training on the hazardous effect of agrochemicals and preventive measures to protect themselves. More also, in developing countries where less than $20 \%$ of the world agrochemical production are consumed, agrochemicals have been reported to account for $70 \%$ of acute poisoning among working population (United States Environmental Protection Agency [USEPA], 2016). In Nigeria, Ojo (2016), identified the following as factors that aggravate health hazards from pesticide use; the use of the cheaper but deadliest types of pesticides (in terms of persistence and toxicity); poor pesticide education leading to extensive misuse; pesticides residues on locally consumed products, poor legislation and lack of enforcement of available legislation; inadequate information, awareness and knowledge of the inherent dangers of pesticides and inadequacies in medical recognition and responses to pesticide poisoning and failure of regulatory systems.

Breast and prostate cancer have been linked to consumption of beef raised under industrial dairy systems where artificial growth hormones such as recombinant bovine growth hormone 
(rBGH) are administered to animals (Food and Water Watch, 2008). In intensive agriculture, antibiotics are administered to farm animals at unnatural levels and this has been reported to be responsible for some food related infections in human (Sayre, 2009).

Table 1 provides a list of some health implication of some chemicals use in agriculture.

\section{LEGISLATURE AND PESTICIDES USE IN NIGERIA}

Nigerian farmers depend largely on agrochemicals such as fertilizers and pesticides for the control of many insect pests, weeds, and diseases. It was reported that about 125,000130,000 metric tons of pesticides are applied annually in Nigeria (Asogwa and Dongo, 2009). Although organizations such as; National Agency for Foods and Drugs Control (NAFDAC), National Environmental Standards and Regulations Enforcement Agency (NESREA), Cocoa Research Institute of Nigeria (CRIN), and Nigeria Stored Products Research Institute (NSPRI) was established to ensure safe use of pesticides in Nigeria, implementation and enforcement of available policies and legislature are inadequate (Isaa, 2016).

Furthermore the Knowledge of Nigerian farmers on the risk associated with the use of pesticide is very low (Ojo, 2016), as a result, farmers would rather continue to use their time tested product that is deadly than complying with the law that places a ban on the use of such pesticide (Adegbola et al., 2011). Farmers do not take necessary precautions required to prevent dangers associated with the use of agrochemicals (Tijani, 2006). More also in Nigeria, pesticide residues in locally consumed products are not being monitored (Ojo, 2016).

The commonly used pesticide by Cocoa farmers in Ondo State of Nigeria as stated by Tijani (2006) include, Aldrex 20, Basudin, Peronox, Gammalin 20, Unden, Sandoz, Cacaobre Copper sulphate, and Thionex. Most of these chemicals were classified by World Health Organization (WHO) as highly or moderately hazardous Tijani, 2006).

\section{CONTRIBUTION OF MICROBIAL INOCULANT IN SUSTAINABLE MAINTENANCE OF HUMAN HEALTH VIZ A VIS}

\section{Microbial Inoculants as Biofertilizers for Plant Growth, Yields and Nutritional Quality Enhancement}

The need to increase agricultural production to meet the food requirement of the ever increasing world population makes consistent maintenance of soil fertility essential. Biofertilizers which are made up of active microbes are a viable alternative technology to increase food production without jeopardizing human and environmental health (Alori et al., 2017a). Biofertilizers include all organisms which supply or make different nutrients available to plants. Examples are nitrogen fixers, phosphorus solubilizers, potassium solubilizers, sulfur solubilizers, and mycorrhiza, etc. (Pathak and Kumar, 2016).

Substantial contribution of Biofertilizer in sustainable maintenance of human health has been reported. Biofertilizers improve the nutritious properties of fresh vegetables by increasing; the antioxidant activity, the total phenolic compounds and chlorophyll (Khalid et al., 2017). Spinach inoculated with different biofertilizers was found to have 58.72 and $51.43 \%$ higher total phenolic content than the un-inoculated control (Khalid et al., 2017). These secondary metabolites play preventive roles in cancer, neurodegenerative, and cardiovascular disorders (Rodríguez-Morató et al., 2015).

Inoculation of lettuce with Azotobacter chroococcum and Glomus fasciculatum also increased the total phenolic compounds, anthocyanins and carotenoids content of the vegetable (Baslam et al., 2011). Higher (48.02 and 40.46\%)

TABLE 1 | Health implication of some chemicals use in agriculture.

\begin{tabular}{|c|c|c|c|}
\hline $\mathbf{S} / \mathbf{N}$ & Ailment & Type of agrochemical & Author \\
\hline 1 & $\begin{array}{l}\text { Cancer or carcinogenicity, birth defects, reproductive effects, liver or kidney damage, } \\
\text { neurotoxicity, disruption of the endocrine system }\end{array}$ & Pesticides & Sharma and Singhvi, 2017 \\
\hline 2 & Heart attack, Cancer, Strokes, Bowel cancer & Fertilizers, pesticides, herbicides, etc. & Thippeswamy, 2013 \\
\hline 3 & Farmers Hypersensitivity Pneumonitis FHP/Farmer's Lung Disease & Pesticides & Schenker, 1998 \\
\hline 4 & Nervous and reproductive system disorder & Pesticides & Benbrook, 2009 \\
\hline 5 & Asthma & Pesticides & Salam et al., 2004 \\
\hline 6 & Neurological deficits & Pesticides & Meggs and Langely, 1997 \\
\hline 7 & Headache, skin irritation, fatigue and eye irritation & Pesticides & Alvanaja et al., 1996 \\
\hline 8 & Oral-facial clefts & Pesticides & Nurminen, 1995 \\
\hline 9 & Congenital birth defects & Pesticides/fungicides & Garry et al., 1995 \\
\hline 10 & Limb reduction defects associated with organ system anomalies & Pesticides & Lin et al., 1994 \\
\hline 11 & Vomiting, Skin burn, itching, nausea, tiredness, and headaches & Pesticides & Tijani, 2006 \\
\hline 12 & Abdominal pain, cancer, restlessness, reproductive disorder, headaches excessive & Pesticides & Adekunle et al., 2017 \\
\hline
\end{tabular}


flavonoid content (antioxidant) was observed in lettuce coinoculated with G. fasciculatum and Glomus mosseae (Baslam et al., 2011). Antioxidant biosynthesis by Arbuscular Mycorrhizal Fungi (AMF) has been reported (Carlsen et al., 2008; Nisha and RajeshKumar, 2010; Eftekhari et al., 2012). Taie et al. (2008), documented a $75 \%$ increase of phenolic acid biosynthesis in soybean seedlings inoculated with Rhizobacteria. Karthikeyan et al. (2010), found that inoculating Pseudomonas fluorescens and Bacillus megaterium into Catharanthus roseus significantly increased the alkaloid content of the crop.

Some researchers such as (Lakshmipathy et al., 2002; Selvaraj et al., 2008) also reported production of secondary metabolites like phenols, tannins, ortho-dihydroxy, flavonoids, phenols and alkaloids after inoculation of G. mosseae, Bacillus coagulans and Trichoderma viride to Begonia malabarica and Calamus thwaitesii. Health promoting compounds produced by biofertilizers according to other researchers include ferulic acid, flavonols (quercetin, kaempferol), caffeic acid, flavones (luteolin), coumaric acid isorhamnetin-3-gentiobioside-7-glucoside, and chlorogenic acid (Alarcón-Flores et al., 2014).

\section{Mechanisms of Actions by Biofertilizers (PGPR)}

Rhizosphere consists of bacteria named rhizobacteria which either directly or indirectly exert positive effects on plants (Kundan et al., 2015). These soil bacteria colonize plant root and benefit the plants by stimulating its growth and are therefore called plant growth promoting rhizobacteria (PGPR) (Beneduzi et al., 2012). PGPR stimulate plant growth and increase crop yields. PGPR are potential biofertilizers. They are less harmful to the environment and they also reduce the cost of chemical fertilizers. PGPR can also be referred to as plant health promoting rhizobacteria (PHPR) (Kundan et al., 2015). PGPR stimulate plant growth in two ways, directly and indirectly. The direct mechanism of plant growth by PGPR involves either providing the plant with a compound that is produced by the bacterium, such as phytohormones, or facilitating the uptake of certain nutrients from the environment (Glick, 1995b). Indirect mechanisms refer to the ability of PGPR to inhibit the deleterious effects of plant pathogenic organism through production of antagonistic substances or by inducing resistance to pathogens (Glick, 1995a).

\section{Direct Mechanism}

Direct mechanism includes phytohormones production, nitrogen fixation, increasing iron availability, phosphate solubilisation, siderophore, ammonia production, etc. PGPR carried out some of these functions via specific enzymes, which provoke morphological and physiological changes in plants thus enhance plant nutrient and water uptake.

\section{Phytohormones production}

Phytohormones are the chemical messengers that affect gene expression and transcription levels, cellular division and hence plant growth. Phytohormones affect seed germination, emergence of flowering, sex of flowers, senescence of leaves, and fruits (Kundan et al., 2015). Examples of phytohormones produced by PGPR include auxin. It is dominantly produced at the shoot apex, and are transported to the root apical meristem through the shoot vascular cambium and accrued in the quiescent center (QC), which is the columella initials and lateral root cap (Brunoud et al., 2012).

Indole-3-acetic acid (indole acetic acid, IAA) is one of the commonly studied auxins (Spaepen et al., 2007). Most times, IAA is produced in bud and young leaves of plant by several independent biosynthetic pathways (Kundan et al., 2015). It plays ultimate role in growth stimulation by being involved in DNA synthesis. The main function of IAA is cell division, differentiation, cell elongation, and extension. IAA causes a rapid increase in cell wall extensibility in young stems (Kundan et al., 2015). IAA promotes growth of auxiliary bud and bud formation. It also helps in the apical dominance, and also stimulates adventitious and lateral root development and growth (Grobelak et al., 2015). IAA plays important role in leaf and flower abscission (Kundan et al., 2015). Some other compounds like indole-3-acetamide, indole-3-pyruvate, indole3 -acetaldehyde, and 4-chloroindole-3-acetic acid have been reported to have auxin activity (Grobelak et al., 2015; Olanrewaju et al., 2017).

The effect of auxin produce by PGPR is determined by the concentration of plant-synthesized auxin. Hence auxin produced by a PGPR will stimulate root development in cases where the concentration of auxin produced by plant is suboptimal, but will inhibit root development in cases where the concentration of the plant produced auxin is already optimal (Spaepen et al., 2007). IAA is synthesized by at least three biosynthetic pathways and each is named for a key intermediate within the pathway. These pathways include: the indole acetamide (IAM) pathway, the indole pyruvic acid (IPyA) pathway, and the indole acetaldoxime (IAOx)/indoleacetonitrile (IAN) pathway (Duca et al., 2015). Many PGPR can have one, two, or even three functional IAA biosynthesis pathway (Olanrewaju et al., 2017).

Gibberellin (GA) is another phytohormone that has been observed in rhizobacteria. GAs are tetracyclic diterpenoid carboxylic acids with either C20 or C19 carbon skeletons (Hedden and Thomas, 2012). Even though 136 globberelline structures have been identified, only four have been identified in bacteria (Hedden and Thomas, 2012). GAs activate important growth processes such seed germination, stem elongation, flowering, and fruit setting (Zaidi et al., 2015). They improve photosynthesis rate, and chlorophyll content (Khan et al., 2015). GAs stimulate shoot growth and inhibit root growth via the actions of the GA signaling system, and the DELLA repressor which trigger GA-inducing genes (Martínez et al., 2016).

\section{1-Aminocyclopropane-1-carboxylate (ACC) deaminase}

1-Aminocyclopropane-1-carboxylate deaminase is another enzyme produced by some PGPR which facilitate plant growth and development by decreasing ethylene levels. Ethylene is a plant growth hormone produced by approximately all plants and also by different biotic and abiotic processes in soils. Ethylene induces multifarious physiological changes in plants (Ahemad and Kibret, 2014). Ethylene is a growth hormone that has also been established as a stress hormone (Gamalero and Glick, 2015). Biotic and abiotic stress such as 
insect and nematode damage, drought or flood, presence of metals, chemicals (both organic and inorganic), ultraviolet light, extreme temperatures, mechanical wounding as well as fungal and bacterial pathogens triggers increased production of ethylene in plants (Ali et al., 2014). However, its production beyond the threshold levels in plant tissue affects the shoot and root development in plant negatively, but ACC deaminase produced by PGPR will reduce ethylene levels by converting ACC (ethylene precursor) to $\alpha$-Ketobutyrate and ammonia and thereby restoring normal plant development (Olanrewaju et al., 2017). Prior application of ACC deaminase-containing PGPR (microbial inoculant) to plants typically reduce the concentration of ethylene produced by the plants as a result of stress and thereby decreases the damage that the plant incurs from the stress (Glick, 2012).

\section{Siderophores production}

Siderophores are small peptidic molecules which contain side chains and functional groups that provide a high-affinity set of ligands to which ferric ions can bind (Goswami et al., 2016). Microorganisms evolved these highly specific pathways to satisfy nutritional requirements of iron (Beneduzi et al., 2012). Siderophores producing microbes can therefore be classified into four main classes (based on their iron-coordinating functional groups, structural features and type of ligands) namely; carboxylate, hydroxamates, phenol catecholates, and pyoverdines (Crowley, 2006). Bacteria siderophore can prevent or lessen proliferation of pathogen by reducing the amount of iron that is available to a pathogen (Shen et al., 2013).

Siderophore producing PGPR therefore has competitive advantages over other microorganisms in the rhizosphere (Haas and Défago, 2005). Siderophores produced by Chryseobacterium spp. C138 when delivered to the root were effective in the supply of iron in tomato plant (Radzki et al., 2013). Likewise, Siderophore producing Pseudomonas strain showed significant increase in germination and plant growth (Sharma and Johri, 2003).

\section{Nitrogen fixation}

Nitrogen is the most important plant nutrient required for growth and productivity. This is because nitrogen is the basic building block of plant, animal and microorganisms. Nitrogen fixation is the conversion of molecular or atmospheric nitrogen into form utilizable to plant by nitrogen fixing microorganisms using an enzyme system called nitrogenase (Kim and Rees, 1994). This is also known as Biological nitrogen fixation (BNF). BNF mostly occurs at mild temperatures (Raymond et al., 2004). This process consumes significant amount of energy in the form of ATP. The nitrogenase gene (nif) required for $\mathrm{BNF}$ is sensitive to oxygen; to therefore prevent oxygen from inhibiting nitrogen fixation while at the same time providing sufficient oxygen for the bacteroides within the nodule to respire, it is essential that bacterial hemoglobin which can bind free oxygen is introduced (Kundan et al., 2015). It has also been reported that the nif genes consist of structural genes which activate Fe protein, molybdenum, and other regulatory genes which are directly involved in the synthesis and functions of enzyme and they are present in both symbiotic and free living systems (Kundan et al., 2015).

Biological nitrogen fixation include both symbiotic nitrogen fixation and the free living nitrogen fixing system. Symbiotic nitrogen fixers include the following genera, Rhizobium, Achromobacter, Sinorhizobium, Azoarcus, Mesorhizobium, Frankia, Allorhizobium, Bradyrhizobium, Burkholderia, Azorhizobium, and Herbaspirillum (Babalola, 2010a; PérezMontaño et al., 2014; Turan et al., 2016). Some of the important non-symbiotic nitrogen-fixing bacteria include: Azoarcus sp., Herbaspirillum sp., Gluconacetobacter diazotrophicus, and Azotobacter sp. (Vessey, 2003).

\section{Ammonia production}

The soil consists of plant, microbial, and animal residues. The quantitatively most important $\mathrm{N}$ containing molecules in the residue are proteins; chitin and peptidoglycan with the proteins alone comprise $60 \%$ or more of the $\mathrm{N}$ in plant and microbial cells (Sinha, 2014). Organic nitrogen residues in soil organic matter is converted by some PGPR such as the ammonia nitrifyers like Pseudomonas sp. and Bacillus sp. to amino acid and the amino acid is then digested to produce ammonia through the process called ammonification (Geisselera et al., 2010). This is a very important biochemical process in soil because some soil bacteria use the ammonia produced to build their own body protein while some other soil bacteria convert the ammonia to nitrite, e.g., Nitrobacter sp. and then to nitrate, e.g., Nitrosomonas sp. Still other bacteria can reduce ammonia to Nitrogen gas (Alacamo, 2001).

\section{Phosphorus solubilisation}

Phosphorus (P) is an essential element that is necessary for plant growth and development and it is second only to nitrogen (Azziz et al., 2012). P occurs in soil in both organic and inorganic forms which are not available to plant. However, a number of PGPR have been reported to mobilize poorly available phosphorus via solubilisation and mineralization. Examples include Pseudomonas spp., Agrobacterium spp., Bacillus circulans, Azotobacter spp., Bacillus spp., Burkholderia spp., Enterobacter spp., Erwinia spp., Kushneria spp., Paenibacillus spp., Ralstonia spp., Rhizobium spp., Rhodococcus spp., Serratia spp., Bradyrhizobium spp., Salmonella spp., Sinomonas spp., and Thiobacillus spp. (Alori et al., 2017b). The mechanism employed by Phosphorus solubilizing bacteria in promoting plant growth include production of plant growth hormones, promoting the efficiency of BNF and enhancing the availability of some nutrient elements such as iron, zinc, etc. (Wani et al., 2007).

The most important mechanism of inorganic phosphorus solubilisation by PGPR is the production of mineral dissolving compounds such as organic acids, hydroxyl ions, protons, and $\mathrm{CO}_{2}$ (Sharma et al., 2013). Some other mechanisms of mineral phosphate solubilization by PGPR include the production of inorganic acids (such as sulphuric, nitric, and carbonic acids), the production of chelating substances and enzymolysis or liberation of enzymes (Zhu et al., 2011; Alori et al., 2017b). 


\section{Indirect Mechanisms}

Indirect mechanism refers to the ability of PGPR to reduce the deleterious effects of plant pathogens on the growth of crop. This involves synthesizing antibiotics, induced systemic resistance (ISR), synthesizing hydrogen cyanide (HCN), competition and producing lytic enzymes including chitinases, proteases, cellulases, lipases, and 1,3-glucanases that can lyse a portion of the cell walls of many pathogenic fungi. These mechanisms are difficult to study in the system and they are therefore considered critical (Kundan et al., 2015).

\section{Production of antibiotics}

The major mechanism employed by PGPR to combat deleterious effects of plant pathogens is the production of one or more antibiotics (Raaijmakers and Mazzola, 2012). Antibiotics are low molecular weight compounds that are produced by PGPR which are deleterious and critical to important enzymes and metabolism of other microorganisms and thus retard the growth (Kundan et al., 2015). Some plant pathogens can develop resistance against specific antibiotics hence the ability of PGPR to produce one or more antibiotics, enhance their ability to act as effective antagonistic agents against plant pathogens (Glick et al., 2007). Antibiotics produced by antagonistic microbes have biostatic and biocidal effects on soil-borne plant pathogens (Bhattacharyya et al., 2016).

However, Olanrewaju et al. (2017), noted that an antibiotic that is observed to control a pathogen might not be as much effective against another pathogen on the same plant. Likewise, the antibiotic-producing PGPR may exhibit varying differences in its actions at different field conditions. Also, the activity of a biocontrol bacterium can be altered by the method of cultivation and formulation of the biocontrol PGPR in the laboratory and by its mode of application (Glick, 2015).

Bacillus and Pseudomonas spp. have been recognized to produce a variety of antibiotics such as tas A, subtilin, bacilysin, sublancin, iturin, chlorotetain, fengycin, subtilosin, and bacillaene (from Bacillus spp.). Phenazine-1-carboxylic acid (PCA), Zwittermycin A, Cepaciamide A, Karalicin, Pseudomonic acid, Kanosamine, Rhamnolipids, Cepafungins, Azomycin, Butyrolactones, 2,4-Diacetyl Phloroglucinol (DAPG), Aerugine, Pyrrolnitrin and Oomycin A (from Pseudomonas spp.) (Goswami et al., 2016).

\section{Induced systemic resistance}

Induced systemic resistance is a mechanism in which nonpathogenic microbes, such as PGPR, reduce the deleterious effects of plant pathogens by stimulating a resistance mechanism in the plants (Van Loon et al., 1998). This mechanism increases resistance at the particular sites of plants at which induction had occurred, i.e., the defense mechanism of ISR is activated only when there is an attack of pathogenic agent (Kundan et al., 2015). ISR is not pathogen specific but rather top the plant against a range of different pathogens. Jasmonate and ethylene are plant hormones that stimulate plants defense response to pathogens, hence ISR employ these hormones to stimulate resistance mechanism in the plants (Verhagen et al., 2004). It activates the "dormant" defense mechanisms which become expressed in response to external contacts from pathogens or insect. PGPR contribute to sustaining the intrinsic resistance of plant to pathogenic organisms (Enebe and Babalola, 2018).

Plant protection by ISR is controlled by a network of coordinated signaling pathways and these are dominated and regulated by plant hormones sharing signaling components (Pieterse et al., 2014). ISR is regulated by the redox-regulated protein non-expressor of PR genes 1 (NPR1) which is produced in the cytoplasm as an oligomer via intermolecular disulfide bonds (Olanrewaju et al., 2017). Many PGPR has been documented to activate ethylene dependent ISR (Weller et al., 2012; Lucas et al., 2014).

\section{HCN production}

Hydrogen cyanide are secondary metabolite that acts as an effective agent for the biocontrol of weeds. HCN produced by PGPR has the ability to inhibit electron transport chain and energy supply to cell, resulting to death of cells. HCN producing rhizobacteria are therefore effective agent of biological weed control (Kundan et al., 2015). Biocontrol PGPR that produces HCN can also synthesize some cell wall degrading enzymes or antibiotics (Ramette et al., 2006). HCN can also act as an anti-fungi agent. HCN synthesized by PGPR is usually in small quantity, this ensures that the fungi do not develop resistance to the synthesized antifungal thereby enhancing the effectiveness of antifungal (Olanrewaju et al., 2017). HCN ability to inhibit important metalloenzymes including cytochrome $\mathrm{c}$ oxidase affects its toxicity effectiveness (Nandi et al., 2017).

\section{Competition}

Plant growth promoting rhizobacteria can limit the proliferation of pathogenic organisms by competing with them for the sparsely available nutrients. Barahona et al. (2011), reported that some biocontrol PGPR outcompete plant pathogens, either for binding sites on the plant root or for nutrient. As a result, limit the binding of the pathogen to the plant and thereby making it difficult for it to proliferate. However, it has been documented that PGPR competitiveness works in synergy with other biocontrol mechanisms to inhibit the functioning of phytopathogens (Olanrewaju et al., 2017). Figure 1 shows the schematic representation of some of the importance of microbial inoculants in agriculture and their mechanism of actions.

\section{Microbial Inoculants as Biocontrol Agents (Biopesticides, Bioherbicides, Biofungicides)}

Many microorganisms demonstrate antifungal and antibacterial activity and are therefore used as biopesticides (Rani et al., 2018). Microbial inoculants play a critical role in biocontrol technology employed in agricultural ecosystems. The mechanisms of biocontrol exercised by most microbial inoculants could be attributed to release of extracellular hydrolytic enzymes, competition for nutrients and secondary metabolites toxic to plant pathogens at very low concentrations (Rani et al., 2018), while some induce defense responses such as Systemic 


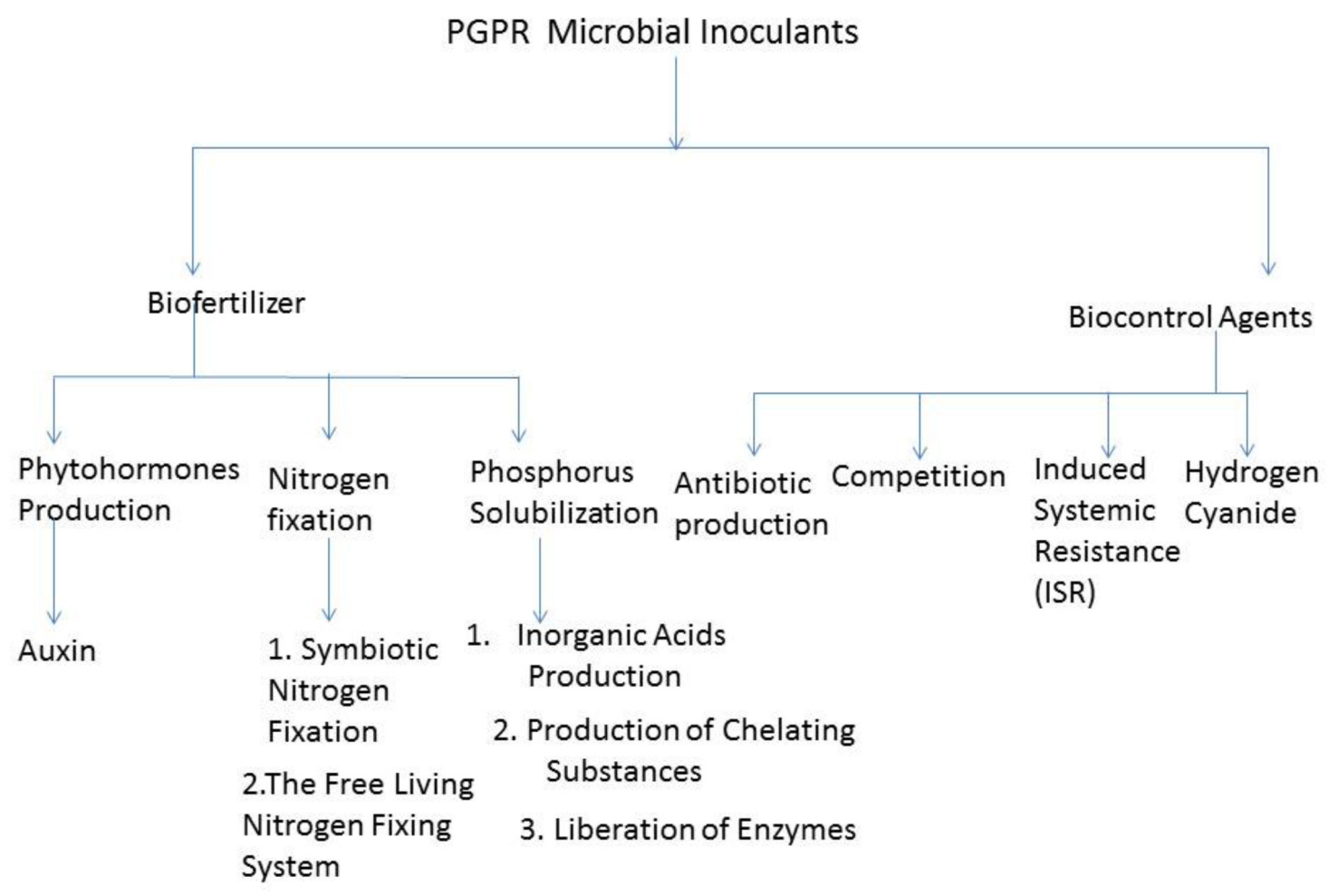

FIGURE 1 | Schematic representation of some importance of Microbial Inoculant in Agriculture and the Mechanism of Actions.

Acquired Resistance in the host plants (Mathivanan et al., 2008). These organisms help in reducing damage to the plants from pathogenic agents and can also modulate the levels of some plant hormones like ethylene and auxin (Glick, 1995a). Beneficial effects of microbial inoculants on plants include control of fungal infections (Babalola and Glick, 2012). Biological control activity exhibited by some microbial inoculants includes herbicidal activity; examples of which include Colletotrichum coccodes a mycoherbicide of velvet leaf, biofungicide of Fusarium spp. (Babalola, 2007) and mycoherbicides of Striga (Zahran et al., 2008). Trichoderma harzianum by producing volatile antibiotics inhibit wood rots and other fungal plant pathogens by up to $60 \%$ (Harman et al., 2004).

Aspergillus fumigatus, Aspergillus niger, Penicillium funiculosum, Penicillium aurantiogriseum, Penicillium citrinum, and Trichoderma koningii have been reported to be effective against plant pathogenic fungi Phytophthora infestans (Rani et al., 2007). More also, Cavaglieri et al. (2005), Pereira et al. (2007), Etcheverry et al. (2009), and (Nesci et al., 2005) have also reported Bacillus amyloliquefaciens, Amphibacillus xylanus, Microbacterium oleovorans, and Sporolactobacillus inulinus to show growth inhibition against fungi pathogens. Bacillus subtilis was reported to control Aspergillus flavus and aflatoxin production both in the field and in the store (Kimura and Hirano, 1988; Nesci et al., 2005). Mitsuaria sp. provide a biocontrol effect on bacterial leaf spot (Cepeda, 2012). Pseudomonads were also reported to exhibit biocontrol effect on Fusarium wilts (Cepeda,
2012). Bacillus spp. has the capacity to produce inhibitory volatile substances and have therefore been reported to be effective in the biological control of microbial diseases in a wide range of plants (Cepeda, 2012). Rhizobia group showed positive effects as biocontrol agents against Pythium disease (Antoun and Prévost, 2005).

\section{Microbial Inoculants in Food Processing}

Microbial inoculants are employed in food processing to improve the nutritional value and food properties such as aroma, taste, texture, safety, and shelf-life (Vitorino and Bessa, 2017). Microbial inoculants are also used for food fermentation and preservation (Borneman et al., 2013). Quite a number of value adding products like vitamins, flavor compounds, enzymes, dyes, and food ingredients are produced by the application of microbial inoculants (Lipkie et al., 2016; Vitorino and Bessa, 2017). Some important pharmacological molecules are also produced using microbial inoculants (Vitorino and Bessa, 2017).

The use of microbial inoculants in food processes improves process efficiency by promoting process control, safety, product quality, yield, and consistency. Many microorganisms have been reported for use in the food and drug processing industries, examples include; Aspergillus spp. which is utilized in alcoholic beverage production. Citric acid produced by $A$. niger is used in food preservation (Mojsov, 2016). Many other microbes are capable of producing polyunsaturated fatty acids, flavoring agents used in food formulations, certain complex 
carbohydrates and amino acids like lysine and glutamic acid (FAO, 2010). More advantages such as lower production costs, the possibility of large-scale production in industrial fermenters, the possibility of genetic manipulation, and rapid culture development are obtained from enzymes sourced from microbes than those from vegetables and animals (Lipkie et al., 2016).

\section{FORMS AND METHODS OF APPLICATION OF MICROBIAL INOCULANTS IN FOOD PRODUCTION}

Microbial inoculants could exist in various forms such as solid or liquid. It could be made up of bacteria or fungi. It could also consist of a pure culture or a mixed culture (Reddy and Saravanan, 2013). There can be various carriers such as peat, clay, and fly ash, coal, saw dust, wheat bran, peat supplemented with chitin-containing materials, inorganic materials such as vermiculite, perlite, silicates, kaolin, and betonies. Carriers for preparing inocula should be designed to provide a favorable microenvironment for the PGPM to ensure their viability and adequate shelf life of the inoculant formulation (preferably 2 months or more at room temperature). A desirable carrier should be easily available, stable, economical, eco-friendly, easy to apply, and have good moisture-holding capacity and $\mathrm{pH}$ buffering capacity (Malusá et al., 2012).

Carrier-type also determines the form of the inoculant (solid or liquid). In the case of solid inocula, the size of the granules or beads used for immobilization of the microbe may vary from 75 to $250 \mu \mathrm{m}$ (Malusá et al., 2012). Liquid inoculants can be broth cultures, suspensions in solutions of humic acid, or suspensions in mineral or organic oils or oilin-water suspensions. Liquid or powder-type inoculants can be used to coat the seeds, for root dipping at the time of transplantation of seedlings, or can be applied directly into the furrow (or seed beds) or as a foliar spray (Reddy and Saravanan, 2013).

\section{CHALLENGES TO THE CONVENTIONAL APPLICATION OF MICROBIAL INOCULANTS IN AGRICULTURE}

Despite the several advantages of microbial inoculant technology over the use of agro-chemicals, it's wide spread utilization is limited by the following challenges. Microbial inoculants have been applied (mainly in research) in the forms of liquids (as sprays, root dips, drenches) or as dry formulations with huge successes recorded, but most of these techniques are not practicable on a large scale. This is because large amount are required for optimum functionality of the inoculants (Callaghan, 2016). PGPR are highly selective and targeted unlike chemical inputs that are broad spectrum product. It only impacts a selected or targeted organism. This therefore results in inconsistency of quality and efficacy under field conditions comprising various organisms act simultaneously (Timmusk et al., 2017).

Another success-limiting factor in the universal utilization of microbial inoculant in agriculture is the variability in shelf-life. It is a serious challenge maintaining viability of microbes present in microbial inoculant formulations (Callaghan, 2016). The viability of microbes in inoculated seeds varied significantly with treatment method and storage temperature. Extended survival of microbial inoculants at ambient storage conditions is recommended for microbial inoculant to become part of the mainstream agriculture. Morealso, as reported by (Callaghan, 2016), the cost of maintaining the viability of both seeds and the microbes during storage is very high.

Furthermore, the use of some microbial inoculants as biocontrol agents can be highly risky. This is because some microbial biocontrol agents have been reported toxic and pathogenic to non-target organisms (Cuddeford and Kabaluk, 2010).

\section{CONCLUSION}

Food production by the use of microbial inoculants is a viable alternative to destructive health effects caused by consumption of food produce by the use of agrochemicals such as pesticides, inorganic fertilizers, herbicides, etc. The knowledge of the mechanisms of actions employed by microbial inoculants will play a vital role in their use in sustainable agriculture. Use of chemicals in agriculture can be avoided and thus they can be removed from human diets. Pest and weed control can be achieved by employing microbial inoculants as biocontrol agents and bio-herbicides. Harnessing natural resources including beneficiary microorganisms is one of the most effective approaches to improving farm productivity and food quality in a sustainable way. Microbial inoculant technology will ensure healthy food security for the future population. We also suggest that those at the helm of authority should review pesticide laws to enhance the effective supervision of pesticide quality and monitoring of existing laws on the use of agrochemicals. There is need to also educate the farmers on the danger associated with indiscriminate use of agrochemicals.

\section{AUTHOR CONTRIBUTIONS}

All authors contributed equally and made a substantial, direct and intellectual contribution to the work, and approved it for publication.

\section{FUNDING}

North-West University granted EA post-doctoral support and OB would like to thank National Research Foundation, South Africa for grant (UID81192), for funds that have supported research in her lab. 


\section{REFERENCES}

Adegbola, J. A., Bamishaiye, E. I., and Olayemi, F. F. (2011). Merchants' attitude towards the use, and ban of the pesticide gammalin in dawanau international grain market, Kano, Nigeria. Adv. Biores. 2, 47-51.

Adekunle, C. P., Akinbode, S. O., Akerele, D., Oyekale, T. O., and Koyi, O. V. (2017). Effects of agricultural pesticide utilization on farmers health in egbeda local govement area, Oyo State, Nigeria Nig. J. Agric. Econ. 7, 73-88.

Ahemad, M., and Kibret, M. (2014). Mechanisms and applications of plant growth promoting rhizobacteria: current perspective. J. King Saud. Univ. Sci. 26, 1-20. doi: 10.1016/j.jksus.2013.05.001

Alacamo, E. (2001). Laboratory Fundamentals of Microbiology. Burlington, MA: Jones and Bartlett Publishers.

Alarcón-Flores, M. I., Romero-González, R., Vidal, J. L., and Frenich, A. (2014). Determination of phenolic compounds in artichoke, garlic and spinach by Ultra-High-Performance Liquid Chromatography coupled to tandem mass spectrometry. Food Anal. Methods 7, 2095-2106. doi: 10.1007/s12161-0149852-4

Ali, S., Charles, T. C., and Glick, B. R. (2014). Amelioration of high salinity stress damage by plant growth-promoting bacterial endophytes that contain ACC deaminase. Plant Physiol. Biochem. 80, 160-167. doi: 10.1016/j.plaphy.2014. 04.003

Alori, E. T., Dare, M. O., and Babalola, O. O. (2017a). "Microbial inoculants for soil quality and plant fitness," in Sustainable Agriculture Review, ed. E. Lichtfouse (Berlin: Springer), 181-308. doi: 10.1007/978-3-319-48006-0

Alori, E. T., Glick, B. R., and Babalola, O. O. (2017b). Microbial phosphorus solubilization and its potential for use in sustainable agriculture. Front. Microbiol. 8:971. doi: 10.3389/fmicb.2017.00971

Alori, E. T., and Fawole, O. B. (2017a). Impact of chemical inputs on arbuscular mycorrhiza spores in soil: response of AM Spores to fertilizer and herbicides. Alban J. Agric. Sci. 16, 10-13.

Alori, E. T., and Fawole, O. B. (2017b). "Microbial inoculants-assisted phytoremediation for sustainable soil management," in Phytoremediation: Management of Environmental Contaminants, Switzerland, eds A. A. Ansari, S. S. Gill, G. R. Lanza, and L. Newman (Berlin: Springer International Publishing), doi: 10.1007/978-3-319-52381-1_1

Alvanaja, M. C., Sandler, D. P., McMaster, S. B., Zahm, S. H., McDonnell, C. J., Lynch, C. F., et al. (1996). The agricultural health study. Environ. Health Perspect. 104, 362-369. doi: 10.1289/ehp.96104362

Antoun, H., and Prévost, D. (2005). "Ecology of plant growth promoting rhizobacteria. PGPR," in Biocontrol and Biofertilization, ed. Z. A. Siddiqui (Berlin: Springer), 1-38. doi: 10.1007/1-4020-4152-7_1

Asogwa, E. U., and Dongo, L. N. (2009). Problems associated with pesticide usage and application in Nigerian cocoa production: a review. Afr. J. Agric. Res. 4, 675-683.

Azziz, G., Bajsa, N., Haghjou, T., Taulé, C., Valverde, A., Igual, J., et al. (2012). Abundance, diversity and prospecting of culturable phosphate solubilizing bacteria on soils under crop-pasture rotations in a no-tillage regime in Uruguay. Appl. Soil Ecol. 61, 320-326. doi: 10.1016/j.apsoil.2011.10.004

Babalola, O. O. (2007). Pectinase and cellulase enhance the control of Abutilon theophrasti by Colletotrichum coccodes. Biocon. Sci. Technol. 17, 53-61. doi: 10.1080/09583150600828783

Babalola, O. O. (2010a). Beneficial bacteria of agricultural importance. Biotechnol. Lett. 32, 1559-1570. doi: 10.1007/s10529-010-0347-0

Babalola, O. O. (2010b). Exogenous cellulase contributes to mycoherbicidal activity of Fusarium arthrosporioideson Orobanche aegyptiaca. Int. J. Aron. 2010:963259. doi: 10.1155/2010/963259

Babalola, O. O., and Glick, B. R. (2012). The use of microbial inoculants in African agriculture: current practice and future prospects. J. Food Agric. Environ. 10, 540-549.

Baker, B., Benbrook, C., Groth, E. III, and Benbrook, K. (2002). Pesticide residues in conventional IPM-growth and organic foods: insights from three data set. Food Addit. Contam. 19, 427-446. doi: 10.1080/02652030110113799

Barahona, E., Navazo, A., Martínez-Granero, F., Zea-Bonilla, T., PérezJiménez, R. M., Martín, M., et al. (2011). Pseudomonas fluorescens F113 mutant with enhanced competitive colonization ability and improved biocontrol activity against fungal root pathogens. Appl. Environ. Microbiol. 77, 5412-5419. doi: 10.1128/AEM.00320-11
Baslam, M., Garmendia, I., and Goicoechea, N. (2011). Arbuscular mycorrhizal fungi (AMF) improved growth and nutritional quality of greenhouse-grown lettuce. J. Agric. Food Chem. 59, 5504-5515. doi: 10.1021/jf200501c

Battu, R. S., Singh, B., Kang, B. K., and Joia, B. S. (2005). Risk assessment through dietary intake of total diet contaminated with pesticide residues in Punjab, India. Ecotoxicol. Environ. Saf. 62, 132-139. doi: 10.1016/j.ecoenv.2004. 12.004

Benbrook, C. (2009). The Organic Factor Tilting the Odd Toward Healthy Development Six Ways Organic Food can Help Prevent Disease Throughout Life. Organic Processing Magazine. Washington, DC: The Organic Center. Available at: http://www.organic-center.org/reportfiles/Organic_Processor_Cover

Beneduzi, A., Ambrosini, A., and Passaglia, L. M. P. (2012). Plant growthpromoting rhizobacteria (PGPR): their potential as antagonists and biocontrol agents. Genet. Mol. Biol. 35 4(Supplement), 1044-1051. doi: 10.1590/S141547572012000600020

Bhandari, G. (2014). An overview of agrochemicals and their effects on environment in Nepal. Appl. Ecol. Environ. Sci. 2, 66-73. doi: 10.12691/aees2-2-5

Bhattacharyya, P. N., Goswami, M. P., and Bhattacharyya, L. H. (2016). Perspective of benefi cial microbes in agriculture under changing climatic scenario: a review. J. Phytol. 8, 26-41. doi: 10.19071/jp.2016.v8.3022

Borneman, A. R., Schmidt, S. A., and Pretorius, I. S. (2013). At the cutting-edge of grape and wine biotechnology. Trends Genet. 29, 263-271. doi: 10.1016/j.tig. 2012.10.014

Brunoud, G., Wells, D. M., Oliva, M., Larrieu, A., Mirabet, V., Burrow, A. H., et al. (2012). A novel sensor to map auxin response and distribution at high spatio-temporal resolution. Nature 482:103. doi: 10.1038/nature10791

Callaghan, M. O. (2016). Microbial inoculation of seed for improved crop performance: issues and opportunities. Appl. Microbiol. Biotechnol. 100, 57295746. doi: 10.1007/s00253-016-7590-9

Carlsen, S., Understrup, A., Fomsgaard, I., Mortensen, A., and Ravnskov, S. (2008). Flavonoids in roots of white clover: interaction of arbuscular mycorrhizal fungi and a pathogenic fungus. Plant Soil 302, 33-43. doi: 10.1007/s11104-0079452-9

Cavaglieri, L., Andrés, L., Ibañez, M., and Etcheverry, M. (2005). Rhizobacteria and their potential to control Fusarium verticillioides, effect of maize bacterisation and inoculum density. Antoinie Van Leeuwenhoek 87, 179-187. doi: 10.1007/ s10482-004-3193-z

Cepeda, M. V. (2012). Effects of Microbial Inoculants on Biocontrol and Plant Growth Promotion Plant Pathology. Master of Science, Ohio State University, Columbus, OH. 102. doi: 10:P10_ACCESSION_NUM:osu1345239027

Crowley, D. E. (2006). "Microbial siderophores in the plant rhizosphere," in Iron Nutrition in Plants and Rhizospheric Microorganisms, eds L. L. Barton and J. Abadía (Dordrecht: Springer), 169-198. doi: 10.1007/1-4020-4743-6_8

Cuddeford, V., and Kabaluk, J. T. (2010). "Alternative regulatory models for microbial pesticides," in The Use and Regulation of Microbial Pesticides in Representative Jurisdictions Worldwide, eds J. T. Kabaluk, A. M. Svircev, M. S. Goettel, and S. G. Woo (St. Paul, MN: IOBC Global), 94-98.

Duca, D., Lorv, J., Patten, C., Rose, D., and Glick, B. (2015). Microbial indole3-acetic acid and plant growth. Anton Van Leeuwenhoek 106, 85-125. doi: 10.1007/s10482-013-0095-y

Eftekhari, M., Alizadeh, M., and Ebrahimi, P. (2012). Evaluation of the total phenolics and quercetin content of foliage in mycorrhizal grape (Vitis vinifera L.) varieties and efect of postharvest drying on quercetin yield. Indus. Crop Product. 38, 160-165. doi: 10.1016/j.indcrop.2012.01.022

Enebe, M. C., and Babalola, O. O. (2018). The influence of plant growthpromoting rhizobacteria in plant tolerance to abiotic stress: a survival strategy. Appl. Microbiol. Biotechnol. 102, 7821-7835. doi: 10.1007/s00253-0189214-Z

Etcheverry, M. G., Scandolara, A., Nesci, A., Vilas Boas, Ribeiro, M. S., Pereira, P., et al. (2009). Biological interactions to select biocontrol agents against toxigenic strains of Aspergillus flavus and Fusarium verticillioides from maize. Mycopathologia 167, 287-295. doi: 10.1007/s11046-008-9177-1

FAO (2010). "Current status and options for biotechnologies in food processing and in food safety in developing countries," in Proceedins of the FAO International Technical Conference Guadalajara, Mexico, 1-37.

Food and Water Watch (2008). Dairy 101. Available at: https://www. foodandwaterwatch.org/problems/factory-farming-food-safety 
Gamalero, E., and Glick, B. R. (2015). Bacterial modulation of plant ethylene levels. Plant Physiol. 169:13. doi: 10.1104/pp.15.00284

Garry, V. F., Kelly, J. T., Sprafka, J. M., Griffith, J., Hansen, J. J., McMullen, K. P., et al. (1995). "Survey of health and characterizations of pesticde use among pesticide applicators in Minnesota," in Agricultural Health and Safety Workplace Environment Sustainability, eds H. H. McDuffie, J. A. Dosman, K. M. Semchuk, S. A. Olenchock, and A. Senthilselvan (Boca Raton, FL: CRC Press). doi: 10.1080/00039896.1994.9954984

Geisselera, D., Horwath, W. R., Joergensen, R. G., and Ludwig, B. (2010). Pathways of nitrogen utilization by soil microorganisms. Soil Biol. Biochem. 42, 20582067. doi: $10.1016 /$ j.soilbio.2010.08.021

Gilchrist, M., Greko, C., Wallinga, D., Beran, G., Riley, D., and Thorne, P. (2007). The potential role of concentrated animal feeding operations in infectious disease epidemics and antibiotics resistance. Environ. Health Perspect. 115, 313-316. doi: 10.1289/ehp. 8837

Glick, B. R. (1995a). Metabolic load and heterologous gene-expression. Biotechnol. Adv. 13, 247-261. doi: 10.1016/0734-9750(95)00004-A

Glick, B. R. (1995b). The enhancement of plant growth by free-living bacteria. Can J. Microbiol. 41, 109-117. doi: 10.1139/m95-015

Glick, B. R. (2012). Plant growth-promoting bacteria: mechanisms and applications. Scientifica 2012:963401. doi: 10.6064/2012/ 963401

Glick, B. R. (2015). Resource Acquisition. Beneficial Plant-Bacterial Interactions. New York, NY: Springer, 29-63. doi: 10.1007/978-3-319-13 921-0

Glick, B. R., Cheng, Z., Czarny, J., and Duan, J. (2007). Promotion of plant growth by ACC deaminase producing soil bacteria. Eur. J. Plant Pathol. 119, 329-339. doi: 10.1007/s10658-007-9162-4

Goswami, D., Thakker, J. N., Dhandhukia, P. C., and Tejada, M. M. (2016). Portraying machanics of plant growth promoting rhizobacteria (PGPR): a review. Cogent Food Agric. 2:11127500. doi: 10.1080/23311932.2015.112 7500

Grobelak, A., Napora, A., and Kacprzak, M. (2015). Using plant growth-promoting rhizobacteria (PGPR) to improve plant growth. Ecol. Engr. 84, 22-28. doi: 10.1016/j.ecoleng.2015.07.019

Haas, D., and Défago, G. (2005). Biological control of soil-borne pathogens by fluorescent pseudomonads. Nat. Rev. Microbiol. 3, 307-319. doi: 10.1038/ nrmicrol129

Harman, G. E., Lorito, M., and Lynch, J. M. (2004). "Uses of Trichoderma spp. to alleviate or remediate soil and water pollution," in Advances in Applied Microbiology, eds A. I. Laskin, J. W. Bennett, and G. M. Gadd (San Diego, CA: Elsevier Academic Press), 313-330. doi: 10.1016/S0065-2164(04)5 6010-0

Hedden, P., and Thomas, S. G. (2012). Gibberellin biosynthesis and its regulation. Biochem. J. 444, 11-25. doi: 10.1042/BJ20120245

Isaa, F. O. (2016). Farmers perception of the quality and accessibility of agrochemicals in kaduna and ondo states of nigeria: implications for policy. J. Agric. Ext. 20, 81-95. doi: 10.4314/jae.v20i1.7

Karthikeyan, B., Joe, M. M., Jaleel, C. A., and Deiveekasundaram, M. (2010). Effect of root inoculation with plant growth promoting rhizobacteria (PGPR) on plant growth, alkaloid content and nutrient control of Catharanthus roseus (L.) G. Don. Nat. Croat. 1, 205-212. doi: 10.1016/j.scienta.2007. 04.013

Khalid, M., Hassani, D., Bilal, M., Asad, F., and Huang, D. (2017). Influence of bio-fertilizer containing beneficial fungi and rhizospheric bacteria on health promoting compounds and antioxidant activity of Spinacia oleracea L. Bot. Stud. 58:35. doi: 10.1186/s40529-017-0189-3

Khan, A. L., Waqas, M., Hussain, J., Al-Harrasi, A., Hamayun, M., and Lee, I. J. (2015). Phytohormones enabled endophytic fungal symbiosis improve aluminum phytoextraction in tolerant Solanum lycopersicum: an examples of Penicillium janthinellum LK5 and comparison with exogenous GA 3. J. Hazard Mater. 295, 70-78. doi: 10.1016/j.jhazmat.2015. 04.008

Kim, J., and Rees, D. C. (1994). Nitrogenase and biological nitrogen fixation. Biochemistry 33, 389-397. doi: 10.1021/bi00168a001

Kimura, N., and Hirano, S. (1988). Inhibitory strains of Bacillus subtilis for growth and aflatoxin-production of aflatoxigenic fungi. Agric. Biol. Chem. 52, 1173-1179. doi: 10.1080/00021369.1988.10868840
Kirkhorn, S., and Schenker, M. B. (2001). Human Health Effects of Agriculture: Physical Diseases and Illnesses, N. A. S. Database, AHS-NET. Available at: http://nasdonline.org/1827/d001772/human-health-effects-of-agriculturephysical-diseases-and.html

Kundan, R., Pant, G., Jadon, N., and Agrawal, P. K. (2015). Plant growth promoting rhizobacteria: mechanism and current prospective. J. Fert. Pestic. 6:9. doi: 10.4172/2471-2728.1000155

Lakshmipathy, R., Chandrika, K., Gowda, B., Balakrishna, A. N., and Bagyaraj, D. J. (2002). Response of Calamus thwaitesii var. canaranus wilde to inoculation with Glomus mosseae, Bacillus coagulans and Trichoderma harzianum. J. Soil Biol. Ecol. 22, 16-21.

Lin, S., Marshall, E. G., and Davidson, G. K. (1994). Potential parental exposure to pesticides and limb reduction defeacts. Scand. J. Work Environ. Health 20, 166-179. doi: 10.5271/sjweh.1412

Lipkie, T. E., Ferruzzi, M., and Weaver, C. M. (2016). Bioaccessibility of vitamin $\mathrm{D}$ from bread fortified with UV-treated yeast is lower than bread fortified with crystalline vitamin D2 and bovine milk. FASEB J. 30:918. doi: 10.1096/fasebj.30. 1_supplement.918.6

Lucas, J. A., García-Cristobal, J., Bonilla, A., Ramos, B., and Gutierrez-Mañero, J. (2014). Beneficial rhizobacteria from rice rhizosphere confers high protection against biotic and abiotic stress inducing systemic resistance in rice seedlings. Plant Physiol. Biochem. 82, 44-53. doi: 10.1016/j.plaphy.2014.05.007

Magauzi, R., Mabaera, B., Rusakaniko, S., Chimusoro, A., Ndlovu, N., Tshimanga, M., et al. (2011). Health effects of agrochemicals among farm workers in commercial farms of Kwekwe district, Zimbabwe. Pan. Afr. Med. J. 9:26. doi: 10.4314/pamj.v9i1.71201

Malusá, E., Sas-Paszt, L., and Ciesielska, J. (2012). Technologies for beneficial microorganisms inocula used as biofertilizers. Sci. World J. 2012:491206. doi: $10.1100 / 2012 / 491206$

Martínez, C., Espinosa-Ruiz, A., and Prat, S. (2016). Gibberellins and plant vegetative growth. Annu. Plant Rev. 49, 285-322. doi: 10.1002/9781119210436. ch10

Mathivanan, N., Prabavathy, V. R., and Vijayanandraj, V. R. (2008). The effect of fungal secondary metabolites on bacterial and fungal pathogens, secondary metabolites in soil ecology. Soil Biol. 14, 129-140. doi: 10.1007/978-3-54074543-3 7

Meggs, W. J., and Langely, R. L. (1997). "Chemical hazards of farming," in Safety and Health in Agriculture, Forestry and Fisheries eds R. L. Langely, R. L. McLymore, W. J. Meggs, and G. R. Roberson (Rockville, MD: Goverment Institutes), 249-266.

Mojsov, K. D. (2016). Aspergillus enzymes for food industries. N. Future Dev. Microb. Biotechnol. Bioeng. 16, 215-222. doi: 10.1016/B978-0-444-63505-1. 00033-6

Nandi, M., Selin, C., Brawerman, G., Fernando, W. G. D., and de Kievit, T. (2017). Hydrogen cyanide, which contributes to Pseudomonas chlororaphis strain PA23 biocontrol, is upregulated in the presence of glycine. Biol. Control 108, 47-54. doi: 10.1016/j.biocontrol.2017.02.008

Nesci, A., Bluma, R., and Etcheverry, M. (2005). In vitro selection of maize rhizobacteria to study potential biological control of Aspergillus section flavi and aflatoxin production. Eur. J. Plant Pathol. 113, 1-13. doi: 10.1007/s10658-0055548-3

Nisha, M. C., and RajeshKumar, S. (2010). Infuence of arbuscular mycorrhizal fungi on biochemical changes in Wedilla chinensis (Osbeck) Merril. Anc. Sci. Life 29:26.

Nurminen, T. (1995). Maternal pesticide exposure and pregnancy outcome. J. Occupat. Environ. Med. 37, 135-140. doi: 10.1097/00043764-19950800000008

Ojo, J. (2016). Pesticides use and health in Nigeria. Ife J. Sci. 8, 981-991.

Olanrewaju, O. O., Glick, B. R., and Babalola, O. O. (2017). Mechanisms of action of plant growth promoting bacteria. World J. Microbiol. Biotechnol. 33:197. doi: 10.1007/s11274-017-2364-9

Önder, M., Ceyhan, E., and Kahraman, A. (2011). Effects of Agricultural Practices on Environment International Conference on Biology, Environment and Chemistry Singapoore: IACSIT Press, 24.

Pathak, D., and Kumar, M. (2016). "Microbial inoculants as biofertilizers and biopesticides," in Microbial Inoculants in Sustainable Agricultural Productivity, eds D. Pratap Singh, H. Bahadur Singh, and R. Prabha (Berlin: Springer), 197-209. 
Pereira, P., Nesci, A., and Etcheverry, M. (2007). Effects of biocontrol agents on Fusarium verticillioides count and fumonisin content in the maize agroecosystem: impact on rhizospheric bacterial and fungal groups. Biol. Control 42, 281-287. doi: 10.1016/j.biocontrol.2007. 05.015

Pérez-Montaño, F., Alías-Villegas, C., Bellogín, R. A., del Cerro, P., Espuny, M. R., Jiménez-Guerrero, I., et al. (2014). Plant growth promotion in cereal and leguminous agricultural important plants: from microorganism capacities to crop production. Microbiol. Res 169, 325-336. doi: 10.1016/j.micres.2013. 09.011

Pieterse, C. M. J., Zamioudis, C., Berendsen, R. L., Weller, D. M., Van Wees, S. C. M., and Bakker, P. A. H. M. (2014). Induced systemic resistance by beneficial microbes. Annu. Rev. Phytopathol. 52, 347-375. doi: 10.1146/ annurev-phyto-082712-102340

Raaijmakers, J. M., and Mazzola, M. (2012). Diversity and natural functions of antibiotics produced by beneficial and plant pathogenic bacteria. Annu. Rev. Phytopathol. 50, 403-424. doi: 10.1146/annurev-phyto-081211-17 2908

Radzki, W., Gutierrez, M. F. J., Algar, E., Lucas, G. J. A., GarcíaVillaraco, A., and Ramos Solano, B. (2013). Bacterial siderophores efficiently provide iron to ironstarved tomato plants in hydroponics culture. Antonie Van Leeuwenhoek 104, 321-330. doi: 10.1007/s10482-013-9954-9

Ramette, A., Moënne-Loccoz, Y., and Défago, G. (2006). Genetic diversity and biocontrol potential of fluorescent Pseudomonads producing phloroglucinols and hydrogen cyanide from Swiss soils naturally suppressive or conducive to Thielaviopsis basicola-mediated black root rot of tobacco. FEMS Microbiol. Ecol. 55, 369-381. doi: 10.1111/j.1574-6941.2005.00 052.x

Rani, A., Bhat, M. N., and Singh, B. P. (2007). Effect of potato phylloplane fungi on potato late blight pathogen Phytophthora infestans. J. Mycol. Plant Pathol. 37, 413-417.

Rani, A., Singh, R., Kumar, P., and Shukla, G. (2018). Pros and cons of fungicides: an overview. Int. J. Engr. Sci. Res. Technol. 6, 112-117.

Raymond, J., Siefert, J. L., Staples, C. R., and Blankenship, R. E. (2004). The natural history of nitrogen fixation. Mol. Biol. Evol. 21, 541-554. doi: 10.1093/molbev/ msh047

Reddy, C. A., and Saravanan, R. S. (2013). Polymicrobial multi-functional approach for enhancement of crop productivity. Adv. Appl. Microbiol. 82, 53-113. doi: 10.1016/B978-0-12-407679-2.00003-X

Rodríguez-Morató, J., Xicota, L., Fitó, M., Farré, M., Dierssen, M., and de la Torre, R. (2015). Potential role of olive oil phenolic compounds in the prevention of neurodegenerative diseases. Molecules 20, 4655-4680. doi: 10. 3390/molecules20034655

Roychowdhury, D., Paul, M., and Banerjee, S. K. (2014). Review on the effects of biofertilizers and biopesticides on rice and tea cultivation and productivity. Int. J. Sci. Engr. Technol. 2, 96-108.

Salam, M. T., Li, Y.-F., Langholz, B., and Gilliland, F. D. (2004). Early-life environmental risk factors for asthma: findings from the Children's Health Study. Environ. Health Perspect. 112, 760-765.

Sayre, L. (2009). The Hidden Link between Factory Farms and Human Illness. Finland, MN: Mother Earth News, Organic Consumers Association. Available at: http://www.motherearthnews.com/Natural-Health/Meat-Poultry-HealthRisk.aspx

Schenker, M. B. (1998). Respiratory health hazards in agriculture. Am. J. Respir. Crit. Care Med. 158, S1-S76. doi: 10.1164/ajrccm.158.supplement_1. rccm1585s1

Schmidt, C. (2002). Antibiotic resistance in livestock: more at stake steak. Environ. Health Perspect. 110, A396-A402. doi: 10.1289/ehp.110a396

Selvaraj, T., S. Rajeshkumar, M. C., Nisha, L. Wondimu, and Tesso, M. (2008). Effect of Glomus mosseae and plant growth promoting rhizomicroorganisms (PGPR's) on growth, nutrients and content of secondary metabolites in Begonia malabarica Lam. Mj. Int. J. Sci. Technol. 2, 516-525.

Sharma, A., and Johri, B. N. (2003). Growth promoting influence of siderophoreproducing Pseudomonas strains GRP3A and PRS9 in maize (Zea mays L.) under iron limiting conditions. Microbiol. Res. 158, 243-248. doi: 10.1078/0944-501300197
Sharma, N., and Singhvi, R. (2017). Effects of chemical fertilizers and pesticides on human health and environment: a review int. J. Agric. Environ. Biotechnol. 10, 675-679. doi: 10.5958/2230-732X.2017. 00083.3

Sharma, S. B., Sayyed, R. Z., Trivedi, M. H., and Gobi, T. A. (2013). Phosphate solubilizing microbes: sustainable approach for managing phosphorus deficiency in agricultural soils. Springerplus 2, 587-600. doi: 10.1186/21931801-2-587

Shen, X., Hu, H., Peng, H., Wang, W., and Zhang, X. (2013). Comparative genomic analysis of four representative plant growth-promoting rhizobacteria in Pseudomonas. BMC Genomics 14:271. doi: 10.1186/1471-216414-271

Sinha, R. K. (2014). Modern Plant Physiology, 2nd Edn. Oxford: Alpha Science International.

Spaepen, S., Vanderleyden, J., and Remans, R. (2007). Indole-3-acetic acid in microbial and microorganism-plant signaling. FEMS Microbiol. Rev. 31, 425-448. doi: 10.1111/j.1574-6976.2007.00072.x

Suyal, D. C., Soni, R., Sai, S., and. Goel, R (2016) "Microbial inoculants as biofertilizer," in Microbial Inoculants in Sustainable Agricultural Productivity, ed. D. P. Singh (New Delhi: Springer India), 311-318. doi: 10.1007/978-81-3222647-5_18

Taie, H. A., El-Mergawi, R., and Radwan, S. (2008). Isofavonoids, favonoids, phenolic acids profles and antioxidant activity of soybean seeds as afected by organic and bioorganic fertilization. Am- Eur. J. Agric. Environ. Sci. 4, 207-213.

Thippeswamy, E. (2013). Comparative analysis of organic and inorganic food. J. Agric. Vet. Sci. 4, 53-57. doi: 10.9790/2380-0465357

Tijani, A. A. (2006). Pesticide use practices and safety issues: the case of cocoa farmers in Ondo State, Nigeria. J. Hum. Ecol. 19, 183-190. doi: 10.1080/ 09709274.2006.11905876

Timmusk, S., Behers, L., Muthoni, J., Muraya, A., and Aronsson, A.-C. (2017). Perspectives and challenges of microbial application for crop improvement. Front. Plant Sci. 8:49. doi: 10.3389/fpls.2017.00049

Turan, M., Kıtır, N., Alkaya, Ü., Günes, A., Tüfenkçi, Ş., Yıldırım, E., and Nikerel, E. (2016). Making soil more accessible to plants: the case of plant growth promoting rhizobacteria. IntechOpen 5, 61-69. doi: 10.5772/ 64826

United States Environmental Protection Agency [USEPA]. (2016). Melathion Human Health Risk Assessment. Washington, DC: USEPA, 258

Van Loon, L., Bakker, P., and Pieterse, C. (1998). Systemic resistance induced by rhizosphere bacteria. Annu. Rev. Phytopathol. 36, 453-483. doi: 10.1146/ annurev.phyto.36.1.453

Verhagen, B. W., Glazebrook, J., Zhu T., Chang, H. S., and van Loon L. C and Pieterse, C. M. (2004). The transcriptome of rhizobacteria-induced systemic resistance in arabidopsis. Mol. Plant Microbe Interact. 17, 895-908. doi: 10.1094/ MPMI.2004.17.8.895

Vessey, J. K. (2003). Plant growth-promoting rhizobacteria as biofertilizers. Plant Soil 255, 571-586. doi: 10.1023/A:102603721 6893

Vitorino, L. C., and Bessa, L. A. (2017). Technological microbiology: development and applications. Front. Microbiol. 8:827. doi: 10.3389/fmicb.2017. 00827

Wani, P. A., Khan, M. S., and Zaidi, A. (2007). Co-inoculation of nitrogen fixing and phosphate solubilizing bacteria to promote growth, yield and nutrient uptake in chickpea. Acta Agron. Hung. 55, 315-323. doi: 10.1556/AAgr.55. 2007.3.7

Weller, D. M., Mavrodi, D. V., van Pelt, J. A., Pieterse, C. M., van Loon, L. C., and Bakker, P. A. (2012). Induced systemic resistance in Arabidopsis thaliana against Pseudomonas syringae pv. tomato by 2, 4-diacetylphloroglucinol-producing Pseudomonas fluorescens. Phytopatholoy 102, 403-412. doi: 10.1094/PHYTO08-11-0222

Wohlfahrt, J., Colin, F., Assaghir, Z., and Bockstaller, C. (2010). Assessing the impact of the spatial arrangement of agricultural practices on pesticide runoff in small catchments: combining hydrological modeling and supervised learning. Ecol. Indic. 10, 826-839. doi: 10.1016/j.ecolind.2010. 01.004

Zahran, E., Sauerborn, J., Abbasher, A. A., Ahmed, E. A., Mohukker, R. I., Karlovsky, P., et al. (2008). "Pesta" and alginate delivery systems of Fusarium 
spp. for biological control of Striga hermonthica (Del.) Benth. under sudanese field conditions. Biol. Control 44, 160-168. doi: 10.1016/j.biocontrol.2007. 10.025

Zaidi, A., Ahmad, E., Khan, M. S., Saif, S., and Rizvi, A. (2015). Role of plant growth promoting rhizobacteria in sustainable production of vegetables: current perspective. Sci. Hortic. 193, 231-239. doi: 10.1016/j.scienta.2015. 07.020

Zhu, F., Qu, L., Hong, X., and Sun, X. (2011). Isolation and characterization of a phosphate solubilizing halophilic bacterium Kushneria sp. YCWA18 from Daqiao Saltern on the coast of yellow sea of China. Evid. Based Complement. Alternat. Med. 2011:615032. doi: 10.1155/2011/61 5032
Conflict of Interest Statement: The authors declare that the research was conducted in the absence of any commercial or financial relationships that could be construed as a potential conflict of interest.

The handling Editor declared a past co-authorship with one of the authors OB.

Copyright (c) 2018 Alori and Babalola. This is an open-access article distributed under the terms of the Creative Commons Attribution License (CC BY). The use, distribution or reproduction in other forums is permitted, provided the original author(s) and the copyright owner(s) are credited and that the original publication in this journal is cited, in accordance with accepted academic practice. No use, distribution or reproduction is permitted which does not comply with these terms. 